\section{Jean de Dieu}

\section{Dushimimana}

Senior lecturer,

Postgraduate School,

University of Kigali,

Rwanda.

E-mail: jdushimimana@

uok.ac.rw

\section{Johan Zaaiman}

Associate professor, Sociology, School of Social Studies, North-West University, South Africa. E-mail: johan.zaaiman@ nwu.ac.za

DOI: https://dx.doi. org/10.18820/24150509/ JCH44.v1.6

ISSN 0258-2422 (Print) ISSN 2415-0509 (Online) Journal for Contemporary History 2019 44(1):107-129

(c) Creative Commons With Attribution (CC-BY)

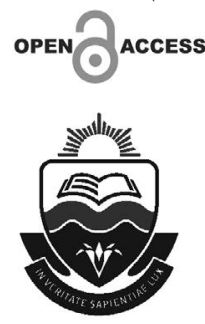

\section{AN EVALUATION OF PARTICIPATION IN LAND REFORM WITHIN RWANDA'S SOUTHERN PROVINCE}

\begin{abstract}
The success of land reform, like other development projects, depends strongly on the participation or involvement of beneficiaries in the various phases. The government of Rwanda has stipulated that the process of its land reform should be participatory, involving beneficiaries and meeting their needs. This article investigates the participation regarding land reform in Rwanda, specifically in the Southern Province.' The study showed that people participated more in the process of land registration than consolidation. The lesser participation in land consolidation was due mostly to a reluctance to abandon multi-culture cropping, for various reasons, even though the farmers were well-informed about the strategy of cultivating priority crops. The article confirms the importance of participation to ensure success in land reform and presents a basis for comparative studies with other regions where inhabitants are involved in similar development.
\end{abstract}

Keywords: Rwanda; land reform; land registration; land consolidation; participation

Sleutelwoorde: Rwanda; grondhervorming; grondregistrasie; grondkonsolidering; deelname

1 The research in this article formed part of the PhD studies of Dr Jean de Dieu Dushimimana who obtained his PhD under the supervision of Prof. S.J. Zaaiman at the North-West University in 2016. This article is based on a section of his thesis: "An Evaluation of Land Reform Implementation in Post-genocide Rwanda: The Case of the Southern Province", (PhD thesis, North-West University, 2016), pp. 101-278. 


\section{INTRODUCTION}

Sub-Saharan African countries have to deal with imbalances between the availability of land and population pressure. Other factors increase pressure on land, namely, unequal access to land ownership, control based mostly on gender, and land-related conflicts. ${ }^{2}$

Rwanda, a small African country, has experienced the same land-related issues over an extended period. The corresponding problems were land-related conflicts, such as land scarcity and insecurity of land tenure, exclusion of women from land access and ownership, and poverty due to insufficient agricultural productivity. ${ }^{3,4,5}$ The post-genocide government that inherited those land issues from the preceding regimes embarked on political, economic and judicial reforms. Their aim was to change the history of land conflict, increase productivity, and further social and economic development. Within those reforms, the land reform programme through land registration and consolidation had a high priority on the policy agenda. The National Land Policy was developed in 2004, and a new land law was promulgated in 2005 and amended in 2013. Thereafter, a land registration programme was developed and implemented nation-wide and people were called to participate actively in the initiative.

This article examines the participation of the population of the Southern Province of Rwanda in the land reform process.

\section{PARTICIPATION IN LAND REFORM}

The success of land registration and consolidation as typical development projects depends strongly on the participation or involvement of beneficiaries in

$2 \quad$ K Deininger, "Forum on Global Land Grabbing: Challenges Posed by the New Wave of Farmland Investment", Journal of Peasant Studies 38(2), 2011, pp. 217-247.

3 H Musahara \& Huggins C, "Land Reform, Land Scarcity and Post Conflict Reconstruction: A Case Study of Rwanda", Eco-conflicts, 2004, 3(3), pp. 1-4.

4 Daley E \& R Dore-Weeks \& C Umuhoza, "Ahead of the Game: Land Tenure Reform in Rwanda and the Process of Securing Women's Land Rights", Journal of Eastern African Studies, 4(1), 2010, pp. 131-152 (here 132).

5 Robin Palmer, "Report and Reflection on the Rwandan Draft National Land Policy Workshop", Mokoro, 2000, <http://mokoro.co.uk/wp-content/uploads/report_and_reflections_rwanda_ draft_nlp_workshop.pdf>, accessed 20 June 2019, p. 2. 
the various phases. ${ }^{6,7,8}$ The population should be involved in land reform, from the development of the policy up to its implementation. The Government of Rwanda has stipulated that the process of land reform would be participatory, involving beneficiaries and meeting their needs.9, 10 Participation entails the involvement of beneficiaries in public decision-making, as well as in the implementation and control of the project. This is done by focusing on their priorities, needs and views in the process." Community development implies that all members participate actively in decision-making that affects their lives, not merely in consultation or through their contribution. Chambers ${ }^{12}$ and Marsden, ${ }^{13}$ who conducted evaluative studies of development projects, observed that when decision-makers disregard beneficiaries' wishes, priorities and concerns, the projects encounter difficulties and often fail.

The assumption, therefore, is that the population who benefit from the programme should be involved throughout the phases of the policy process. This becomes part of the programme's success, by considering the priorities and satisfying the needs of beneficiaries. However, the opposite is also true: If beneficiaries' priorities and needs are not considered, the programme could fail when expectations are not met. According to Rugadya et al., community's involvement and its ability to realise an opportunity to reduce poverty based on land and agrarian reform correlates with stakeholders' sensitisation and awareness or knowledge of the opportunity.14

$6 \quad$ H Musahara, "Improving Tenure Security for Rural Poor: Rwanda -Country Case Study", LEP Working Paper No. 7 (Nakuru: FAO, 2006), p. 16.

7 C Huggins, "Consolidating Land Consolidating Control: What Future for Smallholder Farming in Rwanda's 'Green Revolution'", Paper presented at the International Conference on Global Land Grabbing 2, Cornell University in Ithaca, NY, USA, 17 to 19 October 2012, p. 7.

$8 \quad$ Ali DA \& K Deininger \& M Goldstein, "Environmental and Gender Impacts of Land Tenure Regularisation in Africa: Pilot Evidence from Rwanda", Policy Research Working Paper Series 5765 (Washington, DC: The World Bank, 2011).

9 MINITERRE (Ministry of Lands, Environment, Forestry, Water and Mines) National Land Policy. Kigali: MINITERRE, 2004, p. 31.

10 MINAGRI (Ministry of Agriculture and Animal Resources), Strategic Plan for Transformation of Agriculture in Rwanda Phase II. Final Report (Kigali: MINAGRI, 2009).

11 de Dieu Dushimimana J, Land Tenure Problems and the Rural Youth of Rwanda: The Case of the District of Kamonyi (MA dissertation, Johannesburg: University of the Witwatersrand, 2006).

12 R Chambers, "Shortcut and Participatory Methods for Gaining Information for Projects", in M Cernia, ed., Putting People First: Sociological Variables in Rural Development, 2nd ed. (New York: World Bank, 1991), pp. 515-537.

13 D Marsden, "What is Community Participation?", in Crook R \& A Jerve, eds, Government and Participation: Institutional Development, Decentralisation and Democracy in the Third World (Bergen: Chr. Michelson Institute, 1991), pp. 32-34.

14 Rugadya MA \& E Obaikol \& H Kamusiime, "Gender and the Land Reform Process in Uganda. Assessing Gains and Losses for Women in Uganda", Land Research Series No 6 (Kampala: Associates for Development, 2005), p. 28. 
Effective participation also involves diverse categories of people, including the marginalised, the poor, women and the youth in particular. Over the years, decision-makers of developing countries tended to negate the plight of the poor, women and other vulnerable people. In Africa, particularly the subSaharan region, the concept of the population's participation is well understood in theory, but not really practised in the post-independent era. To the contrary, governments in Africa marginalised the poor (especially women) and excluded them socially, economically and politically. When the poor and women are not empowered, conditions for the marginalised categories do not improve. ${ }^{15}$

To recap, effective policy requires effective participation of the poor in the process, which becomes possible when they are empowered economically. For that purpose, a legal foundation must be provided, and stakeholders who agree to participate in the full implementation must be consulted. ${ }^{16}$ This means that if stakeholders were to participate the project must be demand-driven instead of managed top-down. Similarly, the economic empowerment of the poor requires a commitment by the state to a democratic agenda of development that supports this socio-economic group.

\section{LAND REFORM IN RWANDA}

In Rwanda, the new land policy and land law were developed in 2004 and 2005 respectively. Prior to this, most land in Rwanda was governed by the customary tenure system, while some land in the urban areas and the land owned by the religious missions and businessmen were governed by written law. However, this dual legal system could not solve land-related problems. The main issues were conflicts due to insecure tenure, inequalities in land acquisition, gender-based discrimination regarding access to and ownership of land, and low agricultural productivity as a result of ineffective land use.

From the pre-colonial period to the eve of adopting the current land reform, the political and administrative regimes favoured certain categories of people, namely, local leaders, army generals and businessmen. This helped these favoured people to accumulate more land than the impoverished peasant class. ${ }^{17,} 18$ Increasing demographic density pressurised the available land and the inheritance culture increased land fragmentation. These factors worsened

Ali et al., "Environmental Impacts", 2011, p. 5.

Palmer, "Report", p. 6.

A Kagame, Le code des institutions politiques au Rwanda précolonial (Bruxelles. Institut Royal Colonial Belge, 1952).

18 G Prunier, The Rwandan Crisis: History of Genocide (New York, NY: Colombia University Press, 1995), p. 392. 
land scarcity as the available land could not meet the people's needs. ${ }^{19}, 20,21,22$, ${ }^{23,} 24$ Several studies have shown that the problems surrounding land in Rwanda are due to land scarcity, mainly because of the small size of the country. These problems include issues of unequal land ownership and the imbalances between available land and increasing demographic pressure. ${ }^{25,26,27,28,29,30}$

Rwanda is one of the more rural and densely populated countries in Africa and did not have a strong tenure system, which would have helped to make land more productive. Top-down policy development also undermined the participatory management of land and failed to strengthen social and economic development. This resulted in inefficient land management and deficient administration systems in which the community did not participate. This situation was exacerbated by conflicts such as the genocide of 1994. To help solve these problems, the post-genocide government developed mechanisms that included a land registration programme.

The legal and institutional framework was constructed in the spirit of building national unity and reconciliation and promoting structural transformation. The first legal documents targeting gender-based discrimination were the Inheritance Land Law of 1999, which recognised women's access to land rights, and the Constitution of 2003. Other official documents include the land policy and land law developed successively in 2004 and 2005. This was followed by the establishment of administrative structures and institutions to implement the land registration at central and local levels.

The land policy instituted mechanisms that guarantee the security of tenure to all land users in Rwanda. This was done to promote investment in land through registration and titling. These legal mechanisms entrenched the productive value of land and helped promote the country's socio-economic development. Institutional arrangements were made for land administration, which guaranteed the value of land in the market economy. ${ }^{31}$

\footnotetext{
19 Musahara and Huggins, "Land Reform", p.6.

20 Musahara, "Tenure Security", p. 5.

21 K Boudreaux, "Land Conflicts and Genocide in Rwanda", The Electronic Journal of Sustainable Development 1(3), 2009, pp. 85-94.

22 Ali et al., "Environmental Impacts", p. 15.

23 Daley et al., "Ahead of the Game", p. 14

24 Huggins, "Consolidating Land", p. 8.

25 Boudreaux, "Land Conflicts", p. 85.

26 J Pottier, Social Dynamics of Land and Land Reform in Rwanda (London: University of London, 1997).

27 Musahara and Huggins, "Land Reform", pp. 2, 8.

28 JP Platteau, "Does Africa Need Land Reform?", in Toulmin C \& Julian, eds., Evolving Land Rights, Policy and Tenure in Africa (London: DFID/IIED/NRI, 2000), pp. 51-75.

29 J Pottier, "Land Reform for Peace? Rwanda's 2005 Land Law in Context", Journal of Agrarian Change 6(4), 2006, pp. 509-537.

30 H Musahara, Land and Poverty in Rwanda (Butare: National University of Rwanda, 2001), p. 6.

31 MINITERRE (Ministry of Lands, Environment, Forestry, Water and Mines) National Land Policy. Kigali: MINITERRE, 2004, pp. 4,8.
} 
The participation of the Rwandan population in land registration was managed by statements from legal documents, such as the Constitution of 2003 and the Land Policy and Law of 2004 and 2013. These instruments guarantee equality of Rwandans and prohibit discrimination (including genderbased discrimination) in the access to as well as ownership and use of land. The land policy and law that frame the implementation of land reform highlight the involvement of beneficiaries in the policy process. The aim was that land registration should meet the needs of local people. Thus, people who owned land were sensitised about the benefits of land registration and were involved in the successive steps of the process. ${ }^{32,33}$ For that purpose, people were encouraged to register their plots, while the institutions for land administration and management helped guarantee security of tenure by issuing title deeds to owners and facilitated the best use of land.

Article 4 of the Land Law - No. 43/2013, in particular - recognises land rights of women. This is done by protecting and advocating for those women whose land rights were refused due to custom. The article implies that male and female children receive land equally as an inheritance from their parents, the names of married women appear on the land title documents as co-owners with their husbands, and both wife and children must give their consent for land transactions (see also Art. 21). The legalisation of equal rights for land between men and women promoted equality, furthered women's participation in land registration, and increased their benefits in property rights. However, this participation also increased the number of land heirs and fragmented the land further. This state of affairs hampered the effective participation of women in land registration.

The participatory nature of the policy process and land reform in particular evoked critique from several researchers. They pointed to the top-down leadership and that over an extensive period, rural communities in Rwanda were not empowered. In a 2000 report, Palmer criticised the development of the Rwandan Land Policy Draft of 2001:

Talking of empowerment or participation or of trusting the capabilities of the people even of all local officials is not possible in Rwanda because this country is especially burdened by a centuries-old highly top-down tradition of governance regardless of who is in power. ${ }^{34}$

Palmer also points out that 'most planners in the Ministry of Lands who developed the Land Reform Policy are Kigali-based 'outsiders' who do not know

\footnotetext{
32 MINITERRE (Ministry of Lands, Environment, Forestry, Water and Mines) National Land Policy. Kigali: MINITERRE, 2004, p. 6.

33 MINIRENA (Ministry of Natural Resources), "Law No 43/2013 of 16/06/2013 Governing Land in Rwanda", Official Gazette No. Special of 16/06/2013. (Kigali: MINIRENA, 2013). Palmer, "Report", pp. 2, 11.
} 
Rwandan rural realities well. This can prompt them to develop a policy which does not reflect people's views. ${ }^{35}$

This seems to challenge the promise of the Rwandan Government to make the land registration process more participatory and pro-poor.

Land registration commenced in 2007 with a pilot programme, after which the road map for the regularisation of land tenure was approved by the cabinet in March 2008. An estimated ten million plots of land in Rwanda were registered in terms of 2148 cells. This took place through intended participation with cellland committees.

This article aims to investigate to what extent both activities of registration and consolidation were participatory in the Southern Province of Rwanda. The following section presents the methodology used to collect and analyse the data on this matter.

\section{RESEARCH METHODOLOGY}

The aim of this article was to investigate the population of the Southern Province's participation in post-genocide Rwanda's land reform. For this purpose, data were collected through a mixed-methods approach. The choice for this approach was motivated by the need to explore, describe and evaluate the strengths and weaknesses of land reform implementation in the Southern Province of Rwanda.

The quantitative study formed the major part of the empirical investigation through surveys. Afterwards, a qualitative study was conducted to supplement the results from the quantitative study. The qualitative study consisted of interviews, focus groups and observation.

For the quantitative study, a sample was drawn from the population of eight districts in the Southern Province totalling 2594110 inhabitants $^{36}$ These districts are Kamonyi, Muhanga, Ruhango, Nyanza, Huye, Nyaruguru, Nyamagabe and Gisagara. In addition, two administrative sectors were selected randomly from each district, which provided 16 administrative sectors from a total of 101. Each sector has four cells. Households were selected systematically from the cells. From each household, an adult was identified who enjoyed permanent residence, was literate, and 21 years or older. A sample was drawn of 385 households of land reform beneficiaries (farmers), who answered the posed questions.

35 Palmer, "Report", pp. 6, 11.

36 According to the National Institute of Statistics of Rwanda (NISR), Kigali, 2012, p. 33. 
For the qualitative study, respondents were purposively selected for the interviews as follows:

- 24 rural farmers;

- $\quad$ eight district mayors;

- ten officials of the Rwanda National Resources Authority (RNRA), which is primarily responsible for implementing land registration and titling;

- ten officials of the Rwanda Agricultural Board (RAB), which is responsible for the implementation of land-use consolidation; and

- 29 members of civil society intervening in the land reform implementation process as well as those working in the agriculture sector.

Fifty-six farmers, representing the Southern Province (seven persons per district), were identified for the focus group discussion (FGD). The next section reports on the results of the analysis based on the respondent's feedback concerning their participation in land reform.

\section{EMPIRICAL RESULTS ON PARTICIPATION}

This section presents the study's empirical results based on the respondents' feedback about their participation in land reform within Rwanda's Southern Province. The first activity of the land reform was to introduce the programme to beneficiaries and improve their knowledge. It is, therefore, relevant to establish whether the communities were consulted before the government developed and implemented the national land policy and law for land registration and consolidation. Typically, the involvement in any policy implementation is determined by consultation as well as beneficiaries' and/or implementers' awareness and understanding of the policy. ${ }^{37}$ Secondly, the study had to determine whether communities were involved in the implementation of land reform. The following subsections present the results from the investigation.

\subsection{Participation before land reform was implemented}

There is oral evidence that from 1998 to 2004, the Government of Rwanda organised consultation meetings at the different levels in the various provinces, while the Ministry of Lands was busy writing the land policy. ${ }^{38}$ The present study investigated at which level the respondents of the Southern Province were

37 Rugadya, et al., pp. 3, 21.

38 Musahara and Huggins, "Land Reform", p. 3. 
consulted during the period prior to developing and implementing the national land policy and law.

Table 1 shows the extent to which respondents were consulted before adopting the land-reform policy.

Table 1: Extent to which respondents were consulted before adopting the land-reform policy

\begin{tabular}{|l|c|c|}
\hline Level of consultation before land registration & Frequency & Valid percentage \\
\hline Very high & 11 & 3.2 \\
\hline High & 33 & 9.5 \\
\hline Moderate & 95 & 27.5 \\
\hline Low & 84 & 24.3 \\
\hline Very low & 74 & 21.4 \\
\hline Not at all & 49 & 14.2 \\
\hline Total & 346 & 100.0 \\
\hline Level of consultation before land- & Frequency & Valid percentage \\
\hline use consolidation & 4 & 1.2 \\
\hline High & 36 & 10.4 \\
\hline Moderate & 117 & 33.8 \\
\hline Low & 106 & 30.6 \\
\hline Very low & 83 & 24.0 \\
\hline Not at all & 346 & 100.0 \\
\hline Total & & \\
\hline
\end{tabular}

$n=346$

Table 1 shows that the majority of respondents ranked the consultation before land registration at a moderate level (27.5\%). However, a considerable number rated it at as 'low' (24.3\%) and 'very low' (21.4\%), while $14.2 \%$ indicated no level at all. Regarding consultation for land-use consolidation, most respondents (33.8\%) rated it at a 'low' level (33.8\%); $30.6 \%$ at a 'very low' level; and $24 \%$ at 'no' level. Overall, this means that most farmers were not consulted sufficiently or as much as necessary before implementing both programmes in the Southern Province. 
An interviewed official of Ingabo, a civil society organisation supporting farmers in the south, asserted:

Only local authorities were consulted by MINAGRI [Ministry of Agriculture and Animal Resources] and MINITERE [Ministry of Lands, Environment, Forestry, Water and Mines] about the programme of land registration and consolidation mainly about growing priority crops selected according to the region and they accepted to implement it through the performance contracts without consulting rural dwellers. However, instead of consulting people, they rather told them to implement as the central government authorities told them. (Member of civil society 5, interview, Muhanga District, 5 February 2014).

Other members from the civil society of Haguruka and the Rwanda Initiative for Sustainable Development (ROISD) who were interviewed confirmed that consultation meetings took place. However, the central government officials who organised these meetings consulted local government authorities, opinion leaders and civil society organisations instead of targeting local, ordinary people at the grassroots level (Members of civil society 1 and 2, interview, Kigali, 6 February 2014).

Moreover, these meetings took place at the provincial and district offices and/or in hotels, instead of being held in cells or at the village level.

Several documents reported meetings, such as the preliminary, consultation meetings with local authorities across the country in 1998, which led to the Draft Land Bill. ${ }^{39,40,41,42,43}$ The same documents also reported meetings with different civil society organisations about their view of the Draft National Land Policy of 2001. Further national consultations and consultation meetings, which largely involved local authorities at the district level, took place between 2000 and 2004 in all the provinces.

The civil society organisations were involved in discussions on the drafted land bill and asked to comment during the consultation meetings. However, in effect, they were merely informed since most of their comments (e.g. allowing more time for the sensitisation process) were ignored and only a few considered. This was mentioned by two civil society members who were interviewed (Members of civil society 4 and 5, interview, Kigali, 4 February 2014)

\footnotetext{
39 Palmer, "Report", p. 12.

40 Musahara and Huggins, "Land Reform", p. 3.

41 RISD (Rwanda Initiative for Sustainable Development), "Securing Land Rights Project: A Working Paper on Land Tenure Regularization in Rwanda" RISD Working Paper (Kigali: RISD, 2013).

42 Ali et al., p. 6.

43 MINITERRE (Ministry of Lands, Environment, Forestry, Water and Mines) National Land Policy. Kigali: MINITERRE, 2004, p. 27.
} 
From the responses above, it is clear that at the grassroots level, apart from the local government authorities, none of the other groups who were consulted returned to the villages to inform inhabitants about the objectives of the meetings. This was pointed out by one of the respondents (Respondent 14, interview, Ruhango District, 2 March 2013). The participant from Ingabo explained that due to the low level of consultation and sensitisation at the beginning of the land consolidation a number of people at grassroots resisted the process, whereas the majority participated since 'they feared the public force and to be taken as opponents to the government policies' (Member of civil society, interview, Muhanga District, 5 February 2014).

Normally, land-use consolidation takes place after consulting beneficiaries and acquiring their commitment to participate. The results presented in Table 1, indicate a reason why the land reform was not successful in all regions. There was limited consultation with beneficiaries or landowners before the implementation, especially on the consolidation of land use. A rural farmer interviewee pointed out that only several months after the land reform activities were launched, the local authorities undertook sensitisation campaigns in public meetings and through social media. Their aim was to promote land reform through programmes about land-use consolidation and registration. Table 2 reveals to what extent policymakers actually considered the local farmers' suggestions.

Table 2: The extent to which policy-makers considered the farmers' ideas

\begin{tabular}{|l|c|c|}
\hline $\begin{array}{l}\text { The extent to which farmers' ideas and } \\
\text { suggestions were considered }\end{array}$ & Frequency & Valid percentage \\
\hline High & 2 & 0.6 \\
\hline Moderate & 41 & 11.8 \\
\hline Low & 97 & 28.0 \\
\hline Very little & 131 & 37.9 \\
\hline Not at all & 75 & 21.7 \\
\hline Total & 346 & 100.0 \\
\hline
\end{tabular}

$n=346$

The results from Table 2 indicate that during the consultation meetings organised by local leaders, attendees' ideas and sug'gestions were not really considered. Most respondents (37.9\%) confirmed that their ideas/suggestions were very seldom taken into account; $28 \%$ rated it as 'low'; and $21.7 \%$ rated it at 'not at all'. This reveals a continuation of a top-down policy system in Rwanda. 
The results again support the statement of the report by Palmer that, 'Rwanda also has a centuries-old highly top-down tradition of governance, regardless of who is in power.' ${ }^{44}$ Several researchers such as Sikor and Muller, ${ }^{45}$ and Deininger, ${ }^{46}$ point out that, whether projects of development included land reform or not, they were conceived as top-down mostly with bureaucratic modalities, which inevitably failed.

Thus, according to Table 2, the meetings with local farmers cannot be viewed as consultative or participatory; they were rather informative or sensitising campaigns. This assessment is presented in Table 3, which indicates the sources of knowledge through which the local farmers required information on land reform.

Table 3: Sources of knowledge on land reform acquired

\begin{tabular}{|l|c|c|}
\hline Sources of knowledge acquired & Frequency & Valid percentage \\
\hline During public meeting's & 305 & 98.4 \\
\hline In the media & 5 & 1.6 \\
\hline Total & 310 & 100.0 \\
\hline
\end{tabular}

$n=310$

The results from Table 3 , indicate the ways in which the local farmers became aware of the matters surrounding land. They acquired this information mainly from explanations in public meetings (according to 98.4\%) and received limited knowledge through the media (a mere 1.6\%) before the land registration and consolidation actually commenced. According to the mayors who were interviewed, the local leaders provided information on the land reform during umuganda, which is community work taking place throughout the country in all administrative cells on Saturday of the last week of each month. This finding was corroborated by executive secretaries of all the administrative sectors and people who were interviewed.

In addition, the social media, including public and private radios and television, as well as NGOs, have communicated the content of the land policy and law to rural and urban dwellers, but they seem to have transferred insufficient knowledge. These respondents were asked to recall what they knew

\footnotetext{
44 Palmer, "Report", p. 2.

45 Sikor T \& D Muller, "The Limits of State-Led Land Reform. An Introduction", World Development, 37(8), 2009, pp. 1307-1316.

$46 \quad K$ Deininger, Land Policies for Growth and Poverty Reduction (English). A World Bank Policy Research Report, (Washington, DC: World Bank Group, 2003).
} 
from the explanations by local leaders, whether in public meetings or through the media (albeit limited knowledge). Table 4 provides the results of the interviews.

\section{Table 4: What people learnt about land registration and consolidation}

\begin{tabular}{|c|c|c|}
\hline What people learnt (valid total = 310) & Frequency & Valid percentage \\
\hline Use of fertilisers in modern agriculture & 172 & 55.5 \\
\hline Practising commercial agriculture & 168 & 54.1 \\
\hline $\begin{array}{l}\text { The usefulness of farming collectively, } \\
\text { especially in cooperatives }\end{array}$ & 161 & 51.9 \\
\hline The use of land even on a small plot & 135 & 43.5 \\
\hline $\begin{array}{l}\text { Presenting land title deeds to the bank as a } \\
\text { collateral for a loan }\end{array}$ & 76 & 24.5 \\
\hline $\begin{array}{l}\text { Knowledge on succession law and my land } \\
\text { rights }\end{array}$ & 29 & 9.4 \\
\hline Farming selected crops that fit with the region & 5 & 1.6 \\
\hline $\begin{array}{l}\text { Order in farming, maintenance and effective } \\
\text { use of land }\end{array}$ & 8 & 2.6 \\
\hline Ways of fighting erosion & 6 & 1.9 \\
\hline $\begin{array}{l}\text { Following up crops from sowing to reaping } \\
\text { period }\end{array}$ & 4 & 1.3 \\
\hline $\begin{array}{l}\text { Importance of mono-cropping as well as } \\
\text { land-use consolidation }\end{array}$ & 5 & 1.6 \\
\hline Importance of growing maize & 4 & 1.3 \\
\hline Mixing the manure & 1 & 0.3 \\
\hline The value of land & 1 & 0.3 \\
\hline Nothing & 18 & 5.8 \\
\hline
\end{tabular}

$n=310$

The results presented in Table 4 show consensus among respondents about which aspects of land reform they were informed. As many as $55.5 \%$ of the respondents learnt the importance of fertilisers in modern agriculture; $54.1 \%$ stated that they began practising commercial agriculture; $51.9 \%$ emphasised the usefulness of farming collectively, especially in cooperatives. Other subjects that 
were cited by a few respondents included: efficient use of the small size of land $(43.5 \%)$; presenting a land title deed document to the bank and obtaining loans; and provisions of succession law and people's land rights (9.4\%). From Table 4 it is evident that production issues were central during the deliberations in the Southern Province.

Table 5 reports on respondents' assessment of the explanations they received on the policy and law of land reform.

Table 5: Respondents' assessment of explanations about the land-reform policy and law

\begin{tabular}{|l|c|c|}
\hline Level of explanation & Frequency & Valid percentage \\
\hline Very high & 22 & 6.4 \\
\hline High & 101 & 29.2 \\
\hline Moderate & 106 & 30.6 \\
\hline Low & 40 & 11.6 \\
\hline Very little & 41 & 11.8 \\
\hline Not at all & 36 & 10.4 \\
\hline Total & 346 & 100.0 \\
\hline
\end{tabular}

$n=346$

From Table 5, it is clear that the land reform policy and law were explained to respondents. Most of the respondents $(30.6 \%)$ rated the level of explanation 'moderate', 'low' (11.6\%), 'very little' (11.8\%), or 'not at all' $(10.4 \%)$. The others rated it 'high' (29.2\%) and 'very high' (6.4\%). Interviews with agronomists and mayors of the districts in the Southern Province revealed that certain local leaders often sensitised the people and provided explanations on the programmes, while other leaders did it poorly.

Table 6 presents the assessment of explanations the inhabitants received about the current land policy and law. 
Table 6: Assessment of the explanations on the current land policy and law

\begin{tabular}{|c|c|c|}
\hline Appreciation of level of explanations & Frequency & Valid percentage \\
\hline Very sufficient & 15 & 4.8 \\
\hline Sufficient & 21 & 6.8 \\
\hline Moderate & 99 & 31.9 \\
\hline Insufficient & 98 & 31.6 \\
\hline Very insufficient & 59 & 19.0 \\
\hline Not at all & 18 & 5.8 \\
\hline Total & 310 & 100.0 \\
\hline Subjects not covered & Frequency & Valid percentage \\
\hline $\begin{array}{l}\text { How to prevent problems caused by } \\
\text { drought/climate change }\end{array}$ & 298 & 96.1 \\
\hline Importance of mono-cropping & 287 & 92.6 \\
\hline $\begin{array}{l}\text { Why my land is held through a long } \\
\text { lease }\end{array}$ & 271 & 87.4 \\
\hline Why do we pay land-related taxes? & 258 & 83.2 \\
\hline $\begin{array}{l}\text { Why do women get land through both } \\
\text { biological parents and in-laws? }\end{array}$ & 33 & 10.6 \\
\hline $\begin{array}{l}\text { Why do we not get title deeds for our } \\
\text { lands in marshlands? }\end{array}$ & 32 & 10.3 \\
\hline The reason behind land registration & 28 & 9.0 \\
\hline $\begin{array}{l}\text { Much on crop diseases and how they } \\
\text { should be cured }\end{array}$ & 11 & 3.5 \\
\hline Nothing & 8 & 2.6 \\
\hline How to get loans from the bank & 6 & 1.9 \\
\hline $\begin{array}{l}\text { The reason behind land-use } \\
\text { consolidation }\end{array}$ & 5 & 1.6 \\
\hline
\end{tabular}

$n=310$

The results of Table 6 indicate that the majority of respondents did not strongly appreciate the extent to which explanations were given: $31.9 \%$ rated it 'moderate'; $31.6 \%$ rated it 'insufficient'; and 19\% rated it as 'very insufficient'. 
A limited number of respondents rated it 'sufficient' $(6.8 \%)$; and still fewer as 'very sufficient' $(4.8 \%)$.

Overall, people still lack important skills to participate successfully in land reform, particularly in land-use consolidation. The most prominent topics that were not covered were: how to prevent problems caused by drought/climate change $(96.1 \%)$; the importance of mono-cropping/reasons behind mono-cropping $(92.6 \%)$; why land is held in terms of a long lease, and the limited time for a lease $(87.4 \%)$; while $83.2 \%$ indicated that they do not understand why they were paying land-related taxes. Furthermore, approximately $10 \%$ of respondents sought clarity on why they do not get title deeds for their lands in marshlands, and why women get lands through both biological parents and in-laws; $9 \%$ did not know the reason behind land registration; 3.2\% needed more information about crop diseases and how they should be cured; and 3\% indicated that they do not understand some provisions of the succession law, for example, the matter of land transfer.

In short, based on the analysis of the tables, it can be concluded that the level of consultation with and sensitisation of the beneficiaries before the implementation of land reform was generally low. Furthermore, the interventions by local authorities to explain the key provisions of the land policy and law were insufficient. Farmers were not informed about all the topics of land reform. Nevertheless, a number of topics were addressed jointly with the farmers.

\subsection{Participation in the implementation of land reform}

In light of the previously-mentioned information about consultation meetings and the level of people's awareness of the land policy and law, it was appropriate to investigate whether the population of the Southern Province participated actively in the implementation. It is acknowledged that the success of programmes, such as land reform, aiming to transform the customary land system requires the active participation of the population who are beneficiaries of both land tenure security and land-use consolidation.

The findings showed that most respondents $(98.4 \%)$ confirmed that their land was registered, whilst a small number $(1.6 \%)$ responded in the negative. This indicates that the land registration programme was successful in the Southern Province. In this regard, Article 20 of the Land Law (No. 43/2013 of 16 June 2013) governing land in Rwanda stipulates that land registration is the obligation of all landowners. This means that people had no choice but to participate in the process. The officials in charge of the land survey in the Nyamagabe district who were interviewed mentioned that certain sections of land were not registered. They cited several reasons, for example, the land was subjected to conflict, and landowners had no identity cards or did not meet the required age. An official of the Rwanda National Resources Authority (RNRA) at national level explained it as follows: 
All the lands were registered, and each plot's size was recorded and a number given to it, including those plots subjected to land disputes, even though no land title deed document is issued to the land subjected to disputes. When the land problems are handled by the courts, the owners come here to the Rwanda National Resources Authority office to get the land title deed documents as proof of ownership. (Official of the RNRA 1, interview, Kigali, 22 January 2014).

The land registration was carried out through by surveying land and registering all the names of land rights owners. When comparing the population's participation in the registering of land with that of land-use consolidation, the level of participation in the latter process was found to be lower.

From the results, it was clear that the majority of respondents $(68.5 \%)$ have participated in land-use consolidation, although the number of those who did not participate is also significant (31.5\%). Compared to the land registration programme, the level of participation was found to be higher than in land-use consolidation. Reasons for failing to participate should be linked to the low level of education among the majority of respondents (19.5\% are illiterate, with $58.1 \%$ from primary school level) as well as the poor explanation, inefficient consultation, and insufficient sensitisation about the process.

Table 7 provides reasons respondents gave for not participating in landuse consolidation.

\section{Table 7: Reasons for not participating in land-use consolidation}

\begin{tabular}{|l|c|c|}
\hline $\begin{array}{l}\text { Reasons for not participating in land-use } \\
\text { consolidation }\end{array}$ & Frequency & Valid percentage \\
\hline $\begin{array}{l}\text { Practice multi-culture because I have small } \\
\text { land which is not sufficient for mono-cropping }\end{array}$ & 55 & 45.4 \\
\hline $\begin{array}{l}\text { Dropped it as my first implementation caused } \\
\text { me hunger }\end{array}$ & 17 & 13.9 \\
\hline Do not see any interest in mono-cropping & 10 & 8.2 \\
\hline I do not know nor understand anything about it & 10 & 8.2 \\
\hline $\begin{array}{l}\text { I still practice multi-cropping because it helps } \\
\text { fight hunger }\end{array}$ & 10 & 8.2 \\
\hline My land is not registered & 6 & 4.9 \\
\hline We live in urban area & 2 & 1.6 \\
\hline Total & 121 & 100.0 \\
\hline
\end{tabular}

$n=121$ 
From Table 7, the most prominent reason was the refusal to abandon multiculture cropping (i.e. growing multiple crops), as indicated by 55 respondents $(45.5 \%)$. The reason is that a small land (plot) is unsuitable for mono-cropping. Additions under 'Other significant reasons' were: the failure of the first implementation since it caused hunger; insufficient knowledge about land-use consolidation; and the low level of sensitisation by local leaders.

The discussion shows that the farmers' resistance to active participation could be linked to decision-makers' inability to popularise land-use consolidation and the accompanying mono-cropping programme. It is evident that if people were sensitised and the programme explained better, it could have elicited more collective and active participation of rural farmers. Furthermore, due to insufficient consultation, the policy objectives would most likely not reflect or meet the inhabitants' real needs, not even provisionally. In such cases, effective results cannot be expected, for example, that inhabitants participate fully in the implementation phase. This argument concurs with the observation by Robert Chambers that when developmental projects are initiated without considering the beneficiaries' needs, priorities and concerns, these projects mostly encounter difficulties with uninvolved stakeholders, and often fail. ${ }^{47}$

The beginning of land-use consolidation in the researched area was marked by tensions and opposition from rural people, mainly because they failed to understand the reforms. An agronomist interviewee explained:

In the beginning, people did not massively participate because they thought that the programme aimed to grab their lands whereas today the lack of massive participation is due to small lands and not expecting to grow all the crops they need. (Agronomist 5, interview, Nyanza District, 21 December 2014).

This response shows that local government officials found it difficult to change people's mindsets over such a brief period. There is evidence that public force was used to coerce people who were reluctant to participate in the landuse consolidation. According to participants in the FGDs, at the start, land-use consolidation was forced on those who resisted or totally refused to participate. Cases were even mentioned where local authorities uprooted traditionally farmed crops. A participant from the Gikonkwo sector of the Gisagara District remarked, 'They came to me without informing me and started to uproot banana trees and told me to replace it with maize' (Respondent 14, interview, Gisagara District, 14 January 2014).

The government officials at provincial level who were interviewed acknowledged that forced participation took place in certain areas of the provinces, for example in the sectors of Gikonkwo of the Gisagara District and 
Shyogwe of the Muhanga District. Journalists also reported these incidents, ${ }^{48}$ as did several researchers. ${ }^{49,50}$ However, it was not a decision of the central government to coerce people, uproot their traditional crops and replace it with the regional selected crops. This was rather the result of a misinterpretation by local leaders, as a government official at provincial level elucidated:

No specific meeting took place in which it was decided to uproot people's crops like banana trees; rather, local leaders were told to mobilise people and help them to renew banana trees by planting new / modern ones, for instance, FHIA-17 [type of dessert banana developed].

(Provincial official 1, interview, Nyanza District, 1 December 2014).

Previous studies in other provinces, including the Northern and Eastern Provinces, reported similar cases where farmers' crops were uprooted and replaced with regional crops. For example, Prichard reports that several households in the east and north were ordered to uproot their crops and were forced to develop newly terraced soil. ${ }^{51}$ This led to growing discontent among rural households. Similar cases of crop uprooting took place in the district of Musanze, where farmers had to wait a long time for the maize-seeds approved by the government. They, therefore, decided to plant other crops, which were uprooted forcibly after the approved seeds arrived. ${ }^{52}$

Certain influential leaders and members from civil society who were interviewed reported that people were ordered to participate in mono-cropping. Most accepted simply because of their apprehension to oppose the government's programme. A few rural dwellers who resisted were forced to grow the same selected crop for their region, while those who refused were punished with brief imprisonment. The same interviewees added that local government authorities forced inhabitants to take part in the implementation. The officials did it to gain positive assessments from central government officials. The local officials intended to prove and demonstrate to central government authorities that landuse consolidation was viable and that they were working on it.

48 RA Rwanyange, 'Shyogwe: bamwe ntibarumva gahunda yo guhuza ubutaka', IGIHE, 2013, <http://igihe.com/amakuru/u-rwanda/Shyogwe-Bamwe-ntibarumva-gahunda.html>, accessed 12 February 2013.

49 Huggins, "Consolidating Land", pp. 9, 16.

50 M Milz, "The Authoritarian Face of the 'Green Revolution': Rwanda Capitulates to Agribusiness", Grain, 8 August 2011, <http://www.grain.org/bulletinboard/entries>, accessed 14 February 2013.

51 MF Pritchard, "Land, Power, and Peace: Tenure Systems and the Formalisation Agenda on PostGenocide Rwanda". Presented at the CAPRI International Workshop on Collective action, Property Rights, and Conflicts in Natural Resources Management, Siem Reap, Cambodia, 28 June to 1 July 2019, Slideshare, 4 August 2010, <http://www.slideshare.net/capriaccount/land-power-andpeace-tenure-systems-and-the-formalisation-agenda-in-the-postgenocide-rwanda>, accessed 22 May 2013.

52 Huggins, "Consolidating Land", p. 16. 
In a critical analysis of the land reform policy in Rwanda, Palmer ${ }^{53}$ and Huggins ${ }^{54}$ scrutinise the shortcomings of the policy, for example, the low level of people's participation and insufficient information provided. The authors attributed these impediments to the fact that most planners in the Ministry of Lands who developed the land reform policy are Kigali-based 'outsiders' who were unfamiliar with the Rwandan rural realities. As a result, they developed a policy that does not reflect the people's needs and views. This is evidenced by the persisting top-down development of policy and the tendency of 'political neglect of rural regions' by central government authorities across Africa. ${ }^{55}$

Further reasons for the failure of the land-use consolidation were ineffective consultation, as well as insufficient knowledge about the programmes of land reform. This should be linked to people's limited involvement in the process, as confirmed in the previous argument. This outcome concurs with the view of the benefits theory that the success and achievement of land reform programmes depend on the extent to which the different stakeholders' understand, benefit, accept and are involved in the process. This includes the beneficiaries, civil society and governors.

Regarding the local farmers, the findings show that although they refused to be involved fully in mono-cropping, they were indeed consulted on the priority crops that should be grown, as the majority of respondents $(80.2 \%)$ acknowledged. Thus, it can be inferred that consultation alone is not sufficient to gain local inhabitants' participation. Other matters should also be kept in mind, such as considering people's priorities and needs, as well as proper project management. This argument concurs with the presupposition on which the social exchange theory is founded: If the rewards are considered valuable; the actors are more likely to repeat their previous activities.

Thus, all interviewees who participated in the FGDs and individual interview, corroborated the findings. They mentioned that although they were consulted, the crops the government selected and prescribed for their region were advanced by local authorities, whereas the crops the farmers proposed were ignored. This is confirmed by the following response, 'You see, government authorities used to come to the public meeting's with a list of already selected crops and read them to us. They did not take into consideration our suggestions with regard to those crops' (Respondent 12, interview, Kamonyi District, 14 February 2014).

The implication is clear. When local authorities ignore the local inhabitants' suggestions, the programme fails to elicit people's participation. In support of this, the executive secretary of the Rusatira sector in the Huye District pointed out that

\footnotetext{
53 Palmer, "Report", p. 3.

54 Huggins, "Consolidating Land", p. 12.

55 M Windfuhr, "Food Security, a Global Challenge", in Debiel T et al., eds., Global Trends 2013. Peace - Development - Environment (Bonn: Development and Peace Foundation, 2012), pp. 72-95.
} 
in the beginning, when the programme was launched, people were not opposed to the land-use consolidation or to the order by local authorities. However, when local authorities visited these farmers, they were surprised to observe that the latter in practice did not grow a single crop selected for their region, but rather combined it with other crops they have grown previously.

During the consultation meeting's, farmers suggested growing crops that respond to their needs of improving food security and avoiding famine in the region. These crops included beans, Irish potatoes, sorghum and banana trees. However, the government selected crops such as maize, coffee, and cassava, or rice, even though such crops are grown for the market and not for food security. To address the food shortage, the government relied on market mechanisms through which the national, aggregate productivity of the selected varieties aimed to improve food security. ${ }^{56}$ However, such a process could not succeed, seeing that inhabitants do not regularly buy food at the market; their custom is to reap it from the fields around their homes.

It must also be mentioned that the experiences of inhabitants the Southern Province differ from those of the other provinces, as findings showed from previous research in other parts of Rwanda. This applies particularly to the Northern and Eastern Provinces, which did honour the programme of growing only the government-selected crops. ${ }^{57,58,59}$ However, it must be pointed out that the land-use consolidation drew more participation from the population in the Northern Province since the government's selected seeds of Irish potatoes and maize were usually grown in that region. Moreover, the northern region consists of open flatlands that are easy to cultivate and are therefore useful for land-use consolidation (through mono-cropping). As a result, people became enthusiastically involved in the programme as they received special support from MINAGRI in the form of fertilisers and selected seeds. This is because these farmers were not used to being offered assistance and rather organised themselves in cooperatives. ${ }^{60}$

To summarise, this section presented the empirical results based on respondents' feedback about their participation in land reform within Rwanda's Southern Province. The findings showed that communication on land

56 MINAGRI (Ministry of Agriculture and Animal Resources), Farm Land Use Consolidation in Rwanda: Assessment from the Perspectives of the Agriculture Sector, (Kigali: MINAGRI, 2012).

57 Huggins, "Consolidating Land", pp. 11, 19.

58 JG Hahirwa, "Resistance to Reform: Agricultural Transformation in Post-Genocide Rwanda. An Embedded Case Study Design with the Gako-Masaka Unit of Analysis". Paper presented at the Swedish National Conference on Peace and Conflict Research, University of Gothenburg, 14 to 15 June 2012.

59 A Ansoms, "Modernizing the Marshes: Large-Scale Cultivation and Local desperation". Paper presented at the Conference on Rwanda from Below, University of Antwerp, 29 to 30 June 2012. Huggins, "Consolidating Land", p. 23. 
reform did take place between the authorities and the involved communities. This communication, however, consisted of presentations of information rather than consultation. Not all the concerns of farmers were covered in the presentations. Finally, farmers found it especially challenging to participate in the mono-cropping.

\section{CONCLUSION}

The participants in the study attested to limited consultation on land registration, and insufficient sensitisation about land consolidation before both processes were implemented. Where consultation meetings took place, attendees' ideas and suggestions were not really considered. Nevertheless, public meeting's were found to be highly important platforms where information on land policy and law was conveyed to local farmers. Respondents viewed the quality of the information generally on a moderate level, but its applicability on a lower level.

Considering the respondents' participation in the land reform itself, it was found that most took part in land registration, but few in land consolidation. The limited participation in land consolidation is mostly due to a reluctance to abandon multi-culture cropping for a variety of reasons, although the farmers were well-informed of the strategy that promotes priority crops. The fact that farmers' participation in land registration exceeded their involvement in land-use consolidation is mainly because they expected or acquired more benefits from the land registration and titling than from land consolidation. In reality, the land registration and titling provided people with ownership rights, tenure security, and enabled them to use land as capital for productive purposes. In contrast, most did not understand land-use consolidation, nor was it cost-effective in individual households that followed it.

This article discussed the dilemma of participation in the Southern Province. It calls for action from the government to ensure higher participation from the people of this province. Evidently, the farmers face challenges of food shortages and seasonal drought. It could help if people are allowed to plant crops that help them avoid starvation. Farmers should be allowed to cultivate crops that are drought resistant instead of so-called 'cash crops' (i.e. market-oriented cultivation). This will help solve the problem of severe and widespread food insecurity that historically characterised certain areas of the Southern Province. ${ }^{61,62}$

61 Musahara, "Tenure security", 2006, pp. 12, 15.

62 MINECOFIN (Ministry of Economy and Finance), Rwanda National Export Strategy (Kigali: MINECOFIN, 2011). 
Furthermore, the differences were pointed out between the various Rwandan provinces' acceptance of land reform. This article forms a basis on which those differences can be explored further. It can also premise comparative research involving case studies in land reform from other developing countries worldwide. 